\title{
Prevalence of Anti Erythocyte Alloimmunization to Sub-Saharan African Blood Donors
}

\author{
Sekongo Yassongui Mamadou ${ }^{1}$, Dasse Sery Romuald ${ }^{6}$, Altemeyer Anaïs ${ }^{4}$, Soraya Amar ${ }^{4}$, \\ Tayou Claude ${ }^{2}$, Anani Ludovic ${ }^{3}$, Kassogue Kadidia ${ }^{1}$, Geisen Cristof ${ }^{5}$, Herbrich Anne ${ }^{5}$, \\ Kouamenan Sisonie ${ }^{1}$, Konate Seidou ${ }^{1}$ \\ ${ }^{1}$ National Blood Transfusion Center of Côte D'Ivoire, Abidjan, Ivory Coast \\ ${ }^{2}$ Haematology and Blood Transfusion Service of University Teaching Hospital, Yaoundé, Cameroon \\ ${ }^{3}$ Blood Transfusion Agency of Benin, Benin, Nigeria \\ ${ }^{4}$ Transfusion Swiss Red Cross Switzerland, Laupenstrasse, Switzerland \\ ${ }^{5}$ Institute of Transfusion Medicine and Immunohematology, Frankfurt, Germany \\ ${ }^{6}$ Hospitality and University Center of Cocody, Abidjan, Côte D'Ivoire
}

Email address:

sekyass@yahoo.fr (S. Y. Mamadou)

${ }^{*}$ Corresponding author

\section{To cite this article:}

Sekongo Yassongui Mamadou, Dasse Sery Romuald, Altemeyer Anaïs, Soraya Amar, Tayou Claude, Anani Ludovic, Kassogue Kadidia, Geisen Cristof, Herbrich Anne, Kouamenan Sisonie, Konate Seidou. Prevalence of Anti Erythocyte Alloimmunization to Sub-Saharan African Blood Donors. International Journal of Immunology. Vol. 7, No. 2, 2019, pp. 33-36. doi: 10.11648/j.iji.20190702.12

Received: May 4, 2019; Accepted: August 23, 2019; Published: September 6, 2019

\begin{abstract}
A part from any incompatible blood transfusion, anti-erythrocyte alloimmunization is observed to pregnant women. It is the result of the passage of red blood cells carrying antigens different from those of the mother during pregnancy and delivery. The Rhesus D system is the most involved; but there are also other systems involved in this alloimmunization. Non-transfusion alloimmunization is an extremely rare event in the order of 1 of 4000 to women in Europe and in most cases concerns the Rhesus D. In sub-Saharan Africa, there are no statistics collected on foeto-maternal alloimmunization. As part of our postgraduate thesis on the sensitization status of red blood cells to acridine, we used the technique of looking for irregular agglutinins. The goal was to find anti-erythrocyte alloimmunization to blood donors in sub-Saharan Africa. We conducted a two-year multicenter prospective and descriptive study of 903 blood donors in Côte d'Ivoire, Benin and Cameroon. The samples were analyzed in the laboratories of the National Blood Transfusion Center of Côte D'Ivoire and Frankfurt according to the technique of the RAI gel card of the BIORAD company after centrifugation and incubation using test red cells treated with S-303. In the case of a positive reaction, identification is made by a panel of red blood cells in the different blood group systems. In our study population, there is a male predominance with a male/female ratio of 7.42 . We found a very low prevalence of alloimmunization to non-transfused blood donors ( $0.9 \%$ or 8 cases out of 902$)$. 4 anti-erythrocyte antibodies have been identified (1 Ac anti D and 3 AC anti S); 2 pan-agglutination, 2 unidentified Ac (insufficient serum) and suspicion of anti-glutathione. Anti-erythrocyte alloimmunization to sub-Saharan Africa blood donor is about $0.9 \%$ in our series. It remains high compared to European data. This alloimmunization is mainly observed to women with low frequency antigens to black peoples.
\end{abstract}

Keywords: Antierythrocyte, Alloimmization, Subsaharian, Blood Donor

\section{Introduction}

Alloimmunization is defined as the immunization against an antigen that is absent from the individual of the same species of which he has another antigen defining his group. The development of an immunization supposes:

1. Contact between a blood group antigen and the body that does not have it

2. The reaction of the body with the production of specific 
antibodies for the target unknown blood group antigen.

3. Formation of immune complexes at the origin of tissue immunohemolysis. There are two circumstances of immunization.

4. Pheno-incompatible blood transfusions.

5. Pregnancies to women.

Apart from any incompatible blood transfusion, antierythrocyte alloimmunization is observed to pregnant women. It is the result of the passage of red blood cells with antigens different from those of the mother during pregnancy and delivery. The Rhesus D system is the most involved; but there are also other systems involved in this alloimmunization [1] Non-transfusion alloimmunization is an extremely rare event in the order of $1 / 4000$ to women in Europe and in the majority of cases concerns Rhesus D [3-7]. In sub-Saharan Africa, there are no collected statistics on fetal-maternal alloimmunization. In our postgraduate thesis about the sensitization status of blood cells to acridine in Sub-Saharian Africa, we used the technique of irregular agglutinins research. The goal was to find anti-erythrocyte alloimmunization to blood donors in sub-Saharan Africa.

\section{Methodology}

We conducted a multicenter prospective and descriptive study of 903 blood donors collected in Côte d'Ivoire, Benin and Cameroon. The study lasted from June 2015 to January 2017. Blood samples were collected from voluntary blood donors, of all sexes, aged 18 to 65 years, who gave their consent for the study and participated at the medical consultation to donate blood. Blood donors who have been recalibrated for a positive viral marker, those whose additional tube samples may cause a blood volume surge and those who have not given their informed consent to participate to the study have been excluded. Samples were taken on EDTA tube and after centrifugation for 5 minutes at $3400 \mathrm{rpm}$, they were frozen at $-20^{\circ} \mathrm{C}$ (for samples from Cameroon and Benin) before shipment to Côte d'Ivoire and - $80^{\circ} \mathrm{C}$ for samples from the Côte D'Ivoire. Samples from Benin and Cameroon were transported in carboglass to Abidjan. The samples were analyzed according to the technique of the RAI with gel card of the company BIORAD after centrifugation and incubation using test red cells treated with S-303 and glutathion. In the case of a positive reaction, identification is made by a panel of red blood cells in the different blood group systems.

\section{Results}

In our study population, there were 106 women for 787 men (sex-ratio: 7.42). Donors are mostly students in $48 \%$ of cases. In Côte D'Ivoire, we recorded $63 \%$ of regular donors against $37 \%$ of new donors. In Benin and Cameroon, these were new donors in the majority of cases $(75 \%)$.

Table 1. Summary Table of RAI by Source of Samples.

\begin{tabular}{llll}
\hline Country & Number of Sample & Negative & Positive \\
\hline Cameroum & 272 & 266 & 06 \\
Benin & 297 & 296 & 01 \\
Cote d'Ivoire & 334 & 333 & 01 \\
Total & 903 & 895 & 8 \\
\hline
\end{tabular}

We found 6 positive RAI in Cameroon, 1 in Benin and 1 in Ivory Coast.

Overall $R A I$ results

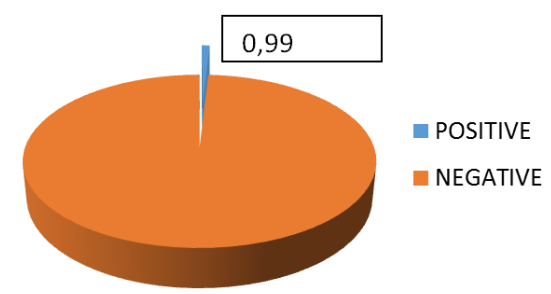

Figure 1. The RAI results

Less than $1 \%$ of Sub-Saharan blood donors have erythrocyte allo antibodies.

Table 2. Results of antibody identification.

\begin{tabular}{lllll}
\hline $\begin{array}{llll}\text { Indentification of } \\
\text { Antibodies }(\mathbf{n}=\mathbf{9})\end{array}$ & \multirow{2}{*}{ Cote D'IVOIRE $(\mathbf{n}=\mathbf{1})$} & Countries & \multirow{2}{*}{ Cameroun $(\mathbf{n}=\mathbf{7})$} \\
\hline Pan-Agglutination & & 0 & 0 & 2 \\
Allo-Antibodies & Anti D & 0 & 0 & 1 \\
& Anti S & & 1 & 2 \\
Others Antibodies & unknown specificity & 0 & 0 & 1 \\
\hline
\end{tabular}

\section{Discussion}

The 903 blood donors collected in the 3 countries namely Côte d'Ivoire (334), Benin (292) and Cameroon (237), all met the criteria for blood donation ability. Our blood donor population is young with an average age of 37.5 years, a minimum age of 21 years and a maximum of 63 years. In Africa, most studies report very young blood donor populations with an average age of 26 years [2-5]. The work of the French blood transfusion research group reported a population of usually young blood donors, with an average age of 26 years (17-60 years) [6]. The average age of our study population is higher than that reported in most African countries. This is due to the fact that for this study we favored the recruitment of regular blood donors; but this could also be due to selection bias as we achieved recruitment only for 3 weeks in a row in the year. We recruited $85 \%$ of men for $15 \%$ of women. The sex ratio is 5.8. Most studies have also shown male predominance 
among blood donors in sub-Saharan Africa with a sex ratio ranging from 3 to 5 men for 1 woman [2-6]. This difference can be explained on the one hand, by many contraindications to blood donation to women including among others the arterial hypotension, anemia, menstruation, pregnancy, the presence of fibroma, breastfeeding and low body weight. Biologically, by technic of Irrigular Agglutinins research (RAI) using red cells test treated with S-303 and glutathione, the presence of possible alloimmunization to blood donors in sub-Saharan Africa was investigated. Apart from the natural erythrocyte antibodies of the ABO system, the presence of an antibody directed against an antigen of another system in most cases, involves blood transfusion [7, 8]. Cases of alloimmunization can be observed to women in obstetric situations. They involve low frequency antigens most often in the mother and high frequency antigens present on the surface of the baby's red blood cells [9-14]. Alloimmunization is a phenomen on very little studied in the African series. Most studies focus on the prevalence of viral markers. However, in the blood products, the studies carried out report significant allo-immunizations between 5 and $30 \%$ [15-22]. In our study, we found a very low prevalence of alloimmunization to non-transfused blood donors $(0.9 \%$ or 8 cases out of 902 donors). In Africa, the frequency of alloimmunization without blood transfusion is not documented. In Europe it is mostly reported in obstetric situations. It is in the order of 1/4000 births in France [23, 24]. In our study, we have 7 alloimmunizations to young women whose average age is 26 years. We were unable to obtain information on obstetrical history, but all were of $\mathrm{O}$ negative blood group. The identification of the antibodies could be made only in 4 cases: - 1 anti-D antibodie- 3 anti S antibodiesThe Côte d'Ivoire sample did not reveal antierythrocyte antibodies. This is probably an anti-glutathione antibody because the red cells test used were treated with S303 and Glutathione. The degradation product of S-303 which is S-300 was not found in the identification of the positive sample. We therefore concluded with the probable presence of an anti-glutathione antibody.

This maternal immunization is the consequence of a foetomaternal incompatibility. It is more important in the MNS system, especially with the $\mathrm{S}$ antigen. Our results are different from those found in Europe. In fact, the European series report 0.9 cases per 1000 births for the foeto-maternal incompatibility against RH D and 0.5 cases per 1000 births for the other systems $[23,24]$.

Indeed, the occurrence of anti-D antibodies to woman outside any transfusion context is explained by an obstetric episode. A mother RH D (-) who has been pregnant with a man RH D runs the risk of developing anti-D antibodies in the event of miscarriage, abortion (IVG) or delivery without administration of serum anti D. In addition to the Rh system, other blood group systems may be involved in alloimmunization apart from any blood transfusion [25, 26]. Very often, these antibodies occur for low frequency antigens as can be observed for the MNS phenotype: $-3,-4,-5$ (S-s-U) in the African population. It is therefore immunization of the mother against the high frequency antigen carried by the fetal red cells. Some specificities of antibodies, such as anti-RH3 (anti-E) or antiRH8 (anti-Cw), are sometimes observed despite the absence of transfusion or obstetric episodes. This hypothesis will be evoked only if it's exclude the implication of the episodes of immunization (transfusion of RBCs negative for the incriminated antigen, no obstetric antecedents involved). Two samples from Cameroon showed pan-agglutination. The identification could not be made for lack of sufficient serum. A third serum from Cameroon had a positive RAI, but for lack of sufficient serum, we were unable to do identification. The pan agglutination was due to the presence of double populations to these blood donors. We were unable to provide an explanation for this because of the lack of epidemiological data on these donors. However, we believe that using caucasiane cells identification could explain the absence or difficulty of identifying certain anti-erythrocyte antibodies to sub saharian African peoples.

\section{Conclusion}

Anti-erythrocyte alloimmunization to sub-Saharan Africa blood donors is about $0.9 \%$ in our series. It remains high compared to European data. This alloimmunization is mainly observed to black women with low frequency antigens. This study demonstrate the importance of performing erythrocyte blood phenotyping to blood donors and also achieving RAI to women. The identification of these antibodies from European red blood cell panel also has a problem. It would therefore be desirable to establish identification panels from black African subjects because the mapping of the erythrocyte phenotypes of the Sub saharians Africans differs from that of the Caucasian. It also involves carrying out complete erythrocyte blood phenotyping of women of childbearing age and comparing it to that of their spouse in case of a child's desire to conceive.

\section{References}

[1] J. C Bensa, B Schweizer. Antigènes et anticorps concernés dans les incompatibilités foeto-maternelles [en ligne]. Disponible sur: «Www.sante.uijfgrenoble.fr» (consulté le 20 octobre 2008).

[2] Rapport d'activité du centre national de transfusion sanguine (CNTS) de Côte D'Ivoire. Conseil de gestion (COGES) Février 2014.

[3] Nébié KY, Olinger CM, Kafando E, Dahourou H, Diallo S, Kientega Y, Domo Y, Kienou K, Ouattara S, Sawadogo I, Ky L, Muller CP. Lack of knowledge among blood donors in Burkina Faso (West Africa); potential obstacle to transfusion security. Transfus Clin Biol. 2007; 14 (5): 446-52.

[4] Tagny CT, Mbanya D, Tapko JB, Lefrere JJ. Blood safety in sub-Saharan Africa: a multi-factorial problem. Transfusion. 2008; 48 (6): 1256-61. 
[5] Christian Ngama Kakisingi et al. Profil épidémiologique et séroprévalence des donneurs de sang aux cliniques universitaires de Lubumbashi, République Démocratique du Congo. The Pan African Medical Journal. 2016; 23: 175.

[6] Tagny CT, Kouao MD, Touré H, et al. Transfusion safety in francophone African countries: an analysis of strategies for the medical selection of blood donors. Transfusion. 2012; 52: 134-43.

[7] J.-Y. Py Risques infectieux et immunologiques de la transfusion érythrocytaire https://www.srlforg/wpcontent/uploads/2015/11/0312-Reanimation-Vol12-N8p564_574.pdf.

[8] J.-J. Lefrère, G. Andreu, C. Barisien, P. Bierling, B. Danic, P. Morel, T. Peyrard, T. Schneider, J. Y Muller Transfusion sanguine, Organisation, bases immunologiques et produits sanguins labiles EMC (Elsevier Masson SAS), Hématologie. 1992; 1984 (12).

[9] M. H. Poissonnier, Y. Brossard, J.-C. Soulié, M. Maynier, M. Larsen, M. Lefevre, J. Chavinié, M. Tournaire. Incompatibilité foto-maternelle érythrocytaire Extrait des Mises à jour en Gynécologie et Obstétrique - Tome XXV publié le 6.12.2001 p119-151.

[10] Chavinié J, Brossard Y. Les incompatibilités sanguines 25 ans après. In: Azoulay M, Mezin R, ed. Xe Journées des Techniques Avancées en Gynécologie-Obstétrique, Périnatologie, PMA. Fort-de-France, 1995: 669-692.

[11] Rigala D, Meyera F, Mayranda E, Dupraza F. Les alloimmunisations foeto-maternelles anti-érythrocytaires: état de l'art en 2008. Revue francophone des laboratoires. 2008; 402: $51-62$.

[12] Bricca P, Guinchard E, Guitton Bliem C. Prise en charge des allo-immunisations foeto-maternelles anti-érythrocytaires. Transfusion Clinique et Biologique. 2011; 18 (2): 269-276.

[13] Carbonne B, Castaigne V, Cynober E, Levy R, Cortey A, Mailloux A, Larsen M, Brossard Y. Le point sur le suivi des allo-immunisations érythrocytaires. Gynécologie Obstétrique \& Fertilité. 2010; 38 (3): 205-213.

[14] C. D'Ercole, Conséquences de l'allo-immunisation foetomaternelle érythrocytaire: Données épidémiologiques. Journal de gynécologie obstétrique et biologie de la reproduction. 2007, 36 (1): S1-S2.

[15] Akré DP, Seka Seka J, Dasse SR, Kplé-Faget P. Alloimmunisation antiérythrocytaire post-transfusionnelle chez les drépanocytaires suivis au CHU de Cocody. J Sci Pharm Biol. 2008; 9 (2): 64-70.
[16] Kabore S, Dembele B, Dasse SR, Sekongo YM, Siransy BL, Yao KD, et al. Allo-immunisation anti-érythrocytaire chez les femmes hémoglobinopathes au CNTS d'Abidjan. Transfus Clin Biol. sept 2017; 24 (3): 339.

[17] Sekongo YM, Kouacou AP, Kouamenan S, Kassogue K, Konan S, N'guessan $\mathrm{P}$, et al. Allo-immunisation antiérythrocytaire chez les drépanocytaires suivis dans l'unité de thérapeutique transfusionnelle $\mathrm{du}$ centre national de transfusion sanguine de Côte d'Ivoire. Transfus Clin Biol. sept 2015; 22 (4): 244-5.

[18] Kangiwa U, Ibegbulam O, Ocheni S, Madu A, Mohammed N. Pattern and prevelence of alloimmunization in multiply transfused patients with sickle cell disease in Nigeria. Biomark Res. oct 2015; 3 (26).

[19] Rosse WF, Gallagher D, Kinney TR, Castro O, Dosik H, Moohr J, et al. Transfusion and alloimmunization in sickle cell disease. The Cooperative Study of Sickle Cell Disease. Blood. Oct 1990; 76 (7): 1431-7.

[20] Verduin EP, Brand A, Schonewille H. Is female sex a risk factor for red blood cell alloimmunization after transfusion? A systematic review. Transfus Med Rev. oct 2012; 26 (4): 34253.

[21] Hussein E, Ahmed Eldesoukey N, Rihan A, Kamal A. Predictors of red cell alloimmunization in multitransfused Egyptian patients with $\beta$-thalassemia. Arch Pathol Lab Med. 2014; 138 (5): 684-8

[22] Alkindi S, AlMahrooqi S, AlHinai S, AlMarhoobi A, AlHosni S, Daar S, et al. Alloimmunization in Patients with Sickle Cell Disease and Thalassemia: Experience of a Single Centre in Oman. Mediterr J Hematol Infect Dis [Internet]. 15 févr 2017; 9 (1). Disponible sur: http://www.ncbi.nlm.nih.gov/pmc/articles/PMC5333756/.

[23] B. Branger, N. Winer, Epidémiologie de l'allo-immunisation anti-D pendant la grossesse. Journal de gynécologie obstétrique et biologie de la reproduction, Fev 2006, 35 (1): 1S87-1S92.

[24] EMC. Allo immunisation fœto-maternelle érythrocytaire [en ligne]. Disponible sur: http: //em-premium.com [consulté le 5 September 2011].

[25] C. D'Ercole, Conséquences de l'allo-immunisation foetomaternelle érythrocytaire: Données épidémiologiques. Journal de gynécologie obstétrique et biologie de la reproduction, Sept 2007; 36 (1): S1-S2.

[26] American Hospital of Paris. Incompatibilité sanguine mèreenfant [en ligne]. Disponible sur «www.americanhospital.org/» (consulté le 28 avril 2008). 